\title{
TITLE:
}

\section{New Records of the Labrid Fish Genus Suezichthys from Japan}

$\operatorname{AUTHOR}(S)$ :

Araga, Chuichi; Masuda, Hajime; Yoshino, Tetsuo

\section{CITATION:}

Araga, Chuichi ... [et al]. New Records of the Labrid Fish Genus Suezichthys from Japan. PUBLICATIONS OF THE SETO MARINE BIOLOGICAL LABORATORY 1988, 33(4-6): 173-178

ISSUE DATE:

1988-12-28

URL:

http://hdl.handle.net/2433/176154

RIGHT: 


\title{
New Records of the Labrid Fish Genus Suezichthys from Japan
}

\author{
By \\ Chuichi Araga \\ Seto Marine Biological Laboratory, Kyoto University, \\ Shirahama, Wakayama, 649-22, Japan

\section{Hajime Masuda} \\ Izu Oceanic Park, Futo, Ito, Shizuoka, 413-02, Japan \\ and

\section{Tetsuo Yoshino} \\ Department of Marine Sciences, University of the Ryukyus, Senbaru 1, \\ Nishihara-cho, Nakagami-gun, Okinawa, 903-01, Japan
}

\section{With Text-figure 1 and Table 1}

Russell (1985, 1986) recognized nine species of Suezichthys from the Indo-Pacific region. Of these, only two species, S. gracilis (Steindachner) and S. notatus (Kamohara), have so far been known from the Japanese waters (Masuda et al. Ed., 1984). Recently we have had a chance to examine each single specimen of the initial and terminal phases (abbreviated as IP and TP, respectively, in the following description) of $S$. arquatus Russell from the eastern coast of Izu Peninsula and each single specimen of the IP and TP of $S$. soelae Russell from the western coast of Okinawa, which provide here the first records of these species from the Japanese waters.

The specimens examined have been deposited at the Seto Marine Biological Laboratory (SMBL), Kyoto University, and Department of Marine Sciences (URM), The University of the Ryukyus.

We would like to express our hearty thanks to Mr. A. Ono of the Zamami Diving Center and Mr. M. Masui of the Umikawa Coral Fish Shop, who kindly offered us important specimens and collecting data.

\section{Suezichthys arquatus Russell}

(Japanese name: Ade-itobera)

(Fig. 1, A, B)

Suezichthys arquatus Russell, 1985, p. 15, pl. III-A, B (type locality: The Poor Knights Islands, New Zealand); Masuda \& Allen, 1987, p. 347, figs H, I.

Material examined. SMBL-F 84031, $105.9 \mathrm{~mm}$ SL, male, off Izu Oceanic Park, eastern coast of Izu Peninsula, Shizuoka Pref., at a depth of $45 \mathrm{~m}$ on a rocky reef, A. Ono with SCUBA and sur-

Publ. Seto Mar. Biol. Lab., Vol. 33(4/6), 173-178, 1988.

(Article 8) 
rounding net, Dec. 1984; SMBL-F 84032, $81.3 \mathrm{~mm}$ SL, female, collecting data same as above.

Counts and proportional measurements are given in Table 1. Body moderately elongate, compressed; profile of head slightly convex. Snout pointed, about 1.4 times as long as eye diameter (in TP specimen) or as long as the latter (in IP specimen). Mouth small, terminal, and horizontal; maxilla reaching a vertical through anterior nostril. Lips moderately fleshy; inside of upper lip with 5 longitudinal plicae; posterior lower lip broad and flap-like, its inside with 2 plicae. Upper jaw with a pair of enlarged canine teeth anteriorly, 12 (in IP) or 13 (in TP) progressively smaller canine teeth laterally; a large canine tooth at the posterior end of upper jaw. Lower jaw with 2 pairs of enlarged canines anteriorly, the inner one longer than the outer; 12 (both in IP and TP) progressively smaller canine teeth laterally. Nostrils small, closely set in front of eye, the anterior one with a short tube, the posterior one with no marginal flap or ridge. Gill membranes not attached to isthmus, forming a free fold posteriorly. Opercular membrane round, extending posterior to pectoral fin base. Forehead, snout, and ventral side of head naked; cheek scale small, in 1 row behind eye and 2 rows below eye. Lateral line complete, bending abruptly downward beneath the 10th dorsal soft ray.

Origin of dorsal fin above the upper end of pectoral fin base; dorsal rays progressively longer posteriorly, the 9 th or 10 th soft ray longest; posterior tip of the fin pointed. Caudal fin round in IP specimen. Caudal fin of TP specimen also round, but with slightly produced, upper and lower lobes. Pectoral fin round, the uppermost branched ray longest, reaching to a point below the base of the 7th dorsal spine. Pelvic fin short, pointed; the 1 st soft ray longest, not reaching a point below the tip of pectoral fin.

Color in alcohol. IP: Head and body pale brownish with 3 longitudinal dark lines behind eye. These lines continuing to anterior $1 / 3$ of the back. Interorbital region dusky, with darker scribblings. A small triangular black spot located on upper base of caudal fin just above the last lateral-line scale. Dorsal fin with 2 black blotches, one on the 1st dorsal membrane basally, the other located near base of the fin over the last 3 rays, much larger than the former and irregular in shape. Caudal fin pale yellowish; distal half of the lower lobe slightly dusky. Anal fin pale with narrow dusky margin. Other fins colorless.

TP: Ground color of head and body dusky except for pale cheek and belly; scales on the side with a darker median band or spot, forming several, continuous or interrupted, longitudinal, brownish stripes on body. Dorsal fin pale with a black spot on the 1st membrane basally, and with an indistinct submarginal dark line on the spinous portion, becoming broader and broken on the soft portion. Posterior blotch on dorsal fin and spot on upper caudal fin base lacking. Caudal fin pale with a faint dusky band obliquely from the upper base to the middle of posterior margin, the lower lobe with dusky posterior margin. Anal fin pale with a narrow black margin. Other fins pale.

Remarks. Our specimens agree well with the original description of S. arquatus by Russell (1985) in most of the characters except for the fresh coloration of both 
IP and TP. The upper part of the body of our IP specimen is reddish instead of the brownish ground color of the original illustration (Russell, 1985, Pl. III-A). The basal half of the anal fin of our TP specimen is not red but yellow instead of the wholly red anal fin of the original illustration (Russel, 1985, Pl. III-B). These differences seem to be due to the condition of specimens (fish fixed just after capture versus living fish underwater-photographed by R.H. Kuiter), or might actually reflect a geographical variation.

Our IP specimen was first observed by the collector at a depth of $75 \mathrm{~m}$, then it was chased up to $45 \mathrm{~m}$ level and caught together with the TP specimen. Underwater pictures of these two fishes was published by Masuda \& Allen, 1987 (p. 347, Figs $H$ and I) with brief ecological comments, but with no taxonomical description.

\section{Suezichthys soelae Russell}

(New Japanese name: Seguro-itobera)

(Fig. 1, C, D)

Suezichthys soelae Russell, 1987, p. 9, p1. II-A, B (type locality: North West shelf, Australia).

Material examined. URM-P 18624, $84.9 \mathrm{~mm}$ SL, male, off Chatan, western coast of Okinawajima, at a depth of $35 \mathrm{~m}$ on a border of rocky area to sandy floor, M. Masui with SGUBA and surrounding net, Jan. 10, 1987; URM-P 1862.5, $66.8 \mathrm{~mm}$ SL, female, collecting data same as above.

Counts and proportional measurements are given in Table 1. Body elongate, compressed; profile of head slightly convex. Snout pointed, about 1.5 times as long as eye diameter. Mouth small, terminal, nearly horizontal; maxilla reaching to a vertical through anterior nostril. Lips fleshy; upper lip with 5 longitudinal plicae; lower lip with a downward flap on its both sides. Upper jaw with a pair of large, recurved canine teeth anteriorly; 10 (in IP specimen) to 13 (in TP specimen) progressively smaller canine teeth laterally; 1 (in IP) or 2 (in TP) large canine teeth at the posterior end of upper jaw. Lower jaw with 2 pairs of large canines anteriorly, the inner one much smaller than the outer; 13 (in TP) or 14 (in IP) progressively smaller canines laterally. Nostrils small, closely set in front of eye, the anterior one terminating in a short tube, the posterior one with no marginal ridge or flap. Gill membranes not attached to isthmus, forming a free fold posteriorly. Opercular membrane round, extending posterior to pectoral fin base. Forehead, snout and ventral side of head naked; cheek scales small, in 2 rows behind eye and in 3 rows below eye. Lateral-line complete, bending abruptly downward beneath 10th dorsal soft ray.

Origin of dorsal fin above posterior tip of opercular membrane; dorsal rays progressively longer posteriorly, the 10th soft ray longest; dorsal fin membrane emarginate, posterior tip of the fin pointed. Origin of anal fin opposite to base of 1st dorsal soft ray; the rays progressively longer posteriorly, the 9th soft ray longest; posterior tip of the fin pointed. Caudal fin nearly truncate in IP specimen, round with slightly produced, upper and lower lobes in TP specimen. Pectoral fin 
Table 1. Counts and proportional measurements of Suezichthys arquatus and S. soelae.

\begin{tabular}{|c|c|c|c|c|}
\hline \multirow{2}{*}{$\begin{array}{r} \\
\ddots \\
\vdots \\
\end{array}$} & \multicolumn{2}{|c|}{ S. arquatus } & \multicolumn{2}{|c|}{ S. soelae } \\
\hline & $\begin{array}{c}\text { SMBL-F } 84031 \\
(\mathrm{TP})\end{array}$ & $\begin{array}{c}\text { SMBL-F 84032 } \\
\text { (IP) }\end{array}$ & $\begin{array}{c}\text { URM-P } 18624 \\
(\mathrm{TP})\end{array}$ & $\begin{array}{c}\text { URM-P } 18625 \\
(\text { IP) }\end{array}$ \\
\hline Total length (mm) & 132.3 & 99.2 & 103.3 & 82.6 \\
\hline Standard length (mm) & 105.9 & 81.3 & 84.9 & 66.8 \\
\hline \multicolumn{5}{|l|}{ Counts } \\
\hline Dorsal fin rays & IX, 11 & IX, 11 & IX, 11 & $\mathrm{IX}, 11$ \\
\hline Anal fin rays & III, 10 & III, 10 & III, 10 & III, 10 \\
\hline Caudal fin rays & vii $+12+$ vii & vii $+12+$ vii & $\mathrm{vii}+12+\mathrm{vii}$ & $\mathrm{vii}+12+$ vii \\
\hline Pectoral fin rays & ii, 12 & ii, 12 & ii, 11 & ii, 11 \\
\hline Pelvic fin rays & $I ; 5$ & I, 5 & I, 5 & $\mathrm{I}, 5$ \\
\hline Pored lateral line scales & 25 & 26 & 25 & 25 \\
\hline Scale rows above $\mathrm{LL}$ & 2. $1 / 2$ & $21 / 2$ & $11 / 2$ & $11 / 2$ \\
\hline Scale rows below LL & $71 / 2$ & $71 / 2$ & $71 / 2$ & $71 / 2$ \\
\hline Predorsal scales & 5 & 5 & 5 & 5 \\
\hline Cheek scale rows behind eye & 1 & 1 & 2 & 2 \\
\hline Cheek scale rows below eye & 2 & 2 & 3 & 3 \\
\hline Gill rackers & 20 & 19 & 18 & $\cdots 17$ \\
\hline \multicolumn{5}{|l|}{ Proportional measurements } \\
\hline Head length (in SL) & 3.03 & 3.02 & 3.17 & 2.97 \\
\hline Body depth & 3.13 & 3.46 & 4.06 & 4.20 \\
\hline Length of dorsal fin base & 1.54 & 1.58 & 1.65 & 1.62 \\
\hline Length of anal fin base & 2.60 & 2.88 & 2.92 & 2.88 \\
\hline Snout length (in HL) & 3.88 & 4.48 & 3.53 & 3.71 \\
\hline Eye diameter & 5.45 & 4.48 & 5.83 & 5.92 \\
\hline Interorbital space & 4.53 & 4.48 & 5.58 & 6.05 \\
\hline Length of 1 st dorsal spine & 4.85 & 6.40 & 6.38 & 6.59 \\
\hline Length of 9th dorsal spine & 2.60 & 3.16 & 2.82 & 2.70 \\
\hline Length of longest dorsal ray. & 2.10 & 2.36 & 2.48 & 2.52 \\
\hline Length of 3rd anal spine & 4.06 & 3.74 & 4.32 & 4.07 \\
\hline Length of longest anal ray & 2.91 & 2.36 & 2.09 & 2.15 \\
\hline Pectoral fin length & 1.58 & 1.79 & 2.03 & 1.91 \\
\hline Pelvic fin length & 2.30 & 2.22 & 1.46 & 1.76 \\
\hline
\end{tabular}

pointed, the uppermost branched ray longest, reaching a point below the base of 7th dorsal spine. Pelvic fin rather long, pointed; the 1st soft ray longest, its tip somewhat filamentous, reaching a vertical below the tip of pectoral fin.

Color in alcohol. IP: Head and body pale yellowish with a dark-edged brownish band from snout through eye and upper part of opercle to the back, and with a brownish spot on upper caudal fin base. Dorsal fin pale with a black spot on the 1st membrane basally. Caudal fin pale with 3 tiny black spots in a diagonal row on the upper lobe. Other fins colorless.

TP: Head and body pale yellowish with a brown band from snout through eye to above opercle, and continuing as a same colored band along the back to upper 
A

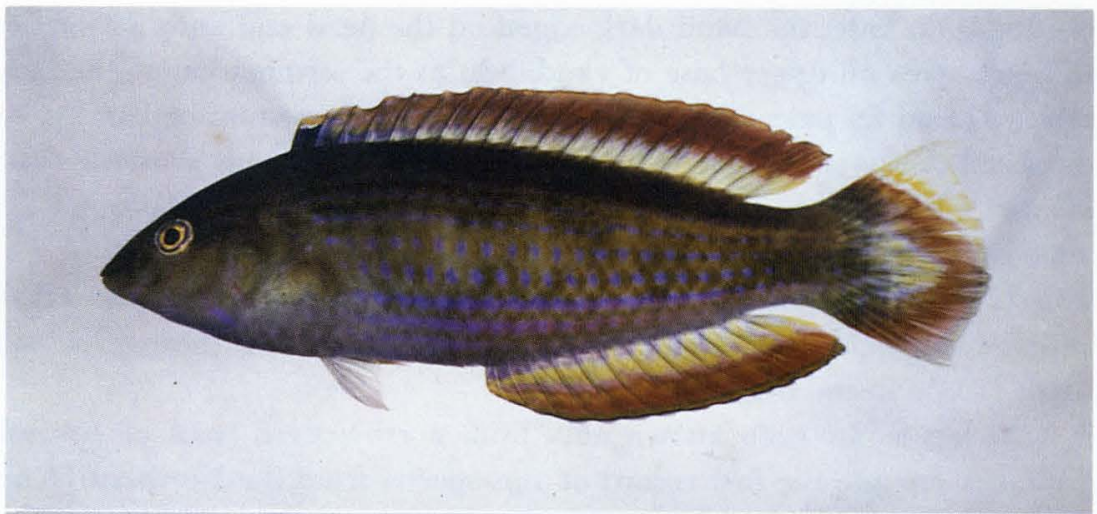

B

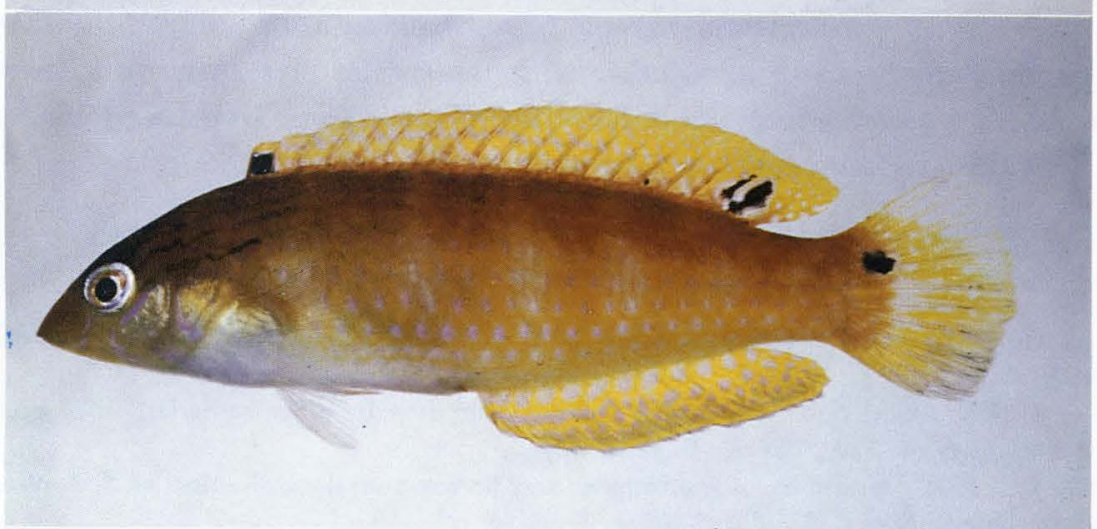

C

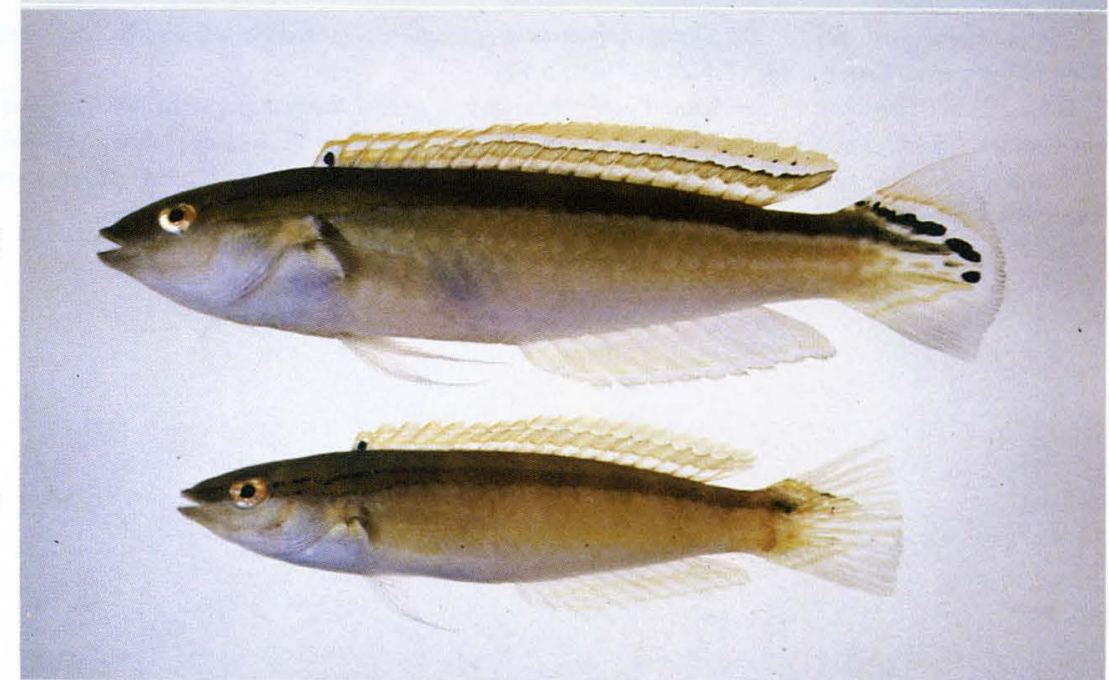

Fig. 1. A. Suezichthys arquatus, TP, SMBL-F $84031,105.9 \mathrm{~mm} \mathrm{SL;} \quad$ B. S. arquatus, IP, SMBL-F 84032, $81.3 \mathrm{~mm}$ SL; $\quad$ C. S. soelae, TP, URM-P $18624,84.9 \mathrm{~mm}$ SL; D. S. soelae, IP, URM-P 18625, $66.8 \mathrm{~mm} \mathrm{SL}$; A and B from Izu Peninsula, photo by A. Ono; C and D from Okinawa, photo by T. Yoshino. 
part of caudal fin base, the band dark-edged on the head and anterior part of body; 3 small black spots on upper base of caudal fin at the termination of the band along the body. Dorsal fin pale with a black spot on the 1st membrane basally, and with a longitudinal dusky stripe medially which is faint on spinous portion. Caudal fin with distinct 5 black spots in an arch from the upper base to middle outer $2 / 3$ of the fin. Other fins colorless.

Remarks. Characteristics of our specimens, including the mcst remarkable pigmentation on the upper caudal lobe of the TP, agree well with those of $S$. soelae given by Russell (1985) in the original description.

S. soelae has so far been known only from northwestern coast of Australia, and our specimens provide the first record of this species from the Northern Hemisphere. Thus, this record represents an example of antiequatorial or antitropical distribution of the Indo-West Pacific fish, together with the species previously menticned in this paper, i.e., S. arquatus, which has hitherto been known from New Caledonia, northern New Zealand, and southwestern coast of Australia.

\section{References}

Masuda, H., K. Amaoka, C. Araga, T. Ueno \& T. Yoshino (Ed.) 1984. The Fishes of the Japanese Archipelago. 437 pp, 370 pls. Tokai University Press, Tokyo.

\& G.R. Allen. 1987. Sea Fishes of the World (the Indo-Pacific Series). 527 pp. Yamakei Publishers Co. Ltd., Tokyo. (In Japanese)

Randall, J.E. 1982. Examples of antitropical and antiequatorial distribution of Indo-West-Pacific fishes. Pacific Sci., (1981) 35: 197-209.

\& A. Kotthaus. 1977. Suezichthys tripunctatus, a new deep-dwelling Indo-Pacific labrid fish. "Meteor" Forsch.-Ergebnisse, (D) 24: 33-36, 3 figs.

Russell, B.C. 1985. Revision of the Indo-Pacific labrid fish genus Suezichthys, with descriptions of four new species. Indo-Pacific fishes No. $2.21 \mathrm{pp}, 3$ pls. Bernice P. Bishop Mus., Hawaii. 1986. A new species of Suezichthys (Pisces, Labridae) from the Great Australian Bight.

Trans. Roy. Soc. S. Aust., 110(2); 59-61, 2 figs. 